\title{
Rainwater Management for Sustaining Groundnut Productivity under Dry Farming Conditions
}

\author{
P.D. Vekaria, V.D. Vora*, T.J. Patel, J.T. Patel, G.R. Sharma, \\ H.R. Vadar and D.S.Hirpara \\ Dry Farming Research Station, Junagadh Agricultural University, \\ Targhadia (Gujarat)-360 003, India \\ *Corresponding author
}

Keywords

Groundnut, FYM, Kaolin, Tillage, rain and crop water use efficiency, yield.

Article Info

Accepted:

15 December 2019 Available Online: 20 January 2020

\section{A B S T R A C T}

A field experiment was conducted during kharif season of 2011-12 to 2016-17 to study the rain water management for sustaining groundnut productivity in medium black soils under dry farming condition at Main Dry Farming Research Station, Junagadh Agricultural University, Targhadia of Nourth Saurashtra Agro climatic Zone of Gujarat. The experiment consisting 2 main plots (2 levels of tillage) and 5 sub plot treatments (Management practices) laid out in split plot design with four replications. Significantly higher pod yield and haulm yield was obtained under the application of FYM @ 10 t/ha and kaolin @ $4 \%\left(\mathrm{M}_{1}\right)$ spray and Ploughing every year up to $20 \mathrm{~cm}$ in set row $\left(\mathrm{T}_{1}\right)$ as compared to control, while it were found non significant in combined effect of tillage and management practice. Maximum rain water use efficiency and crop water use efficiency was recorded in ploughing carried out every year up to $20 \mathrm{~cm}$ in set row $\left(\mathrm{T}_{1}\right)$ practice and application of FYM @10 t/ha + Kaolin@ @\% spray $\left(\mathrm{M}_{1}\right)$ under tillage and management practices, respectively. On the basis of pooled result ploughing carried out in alternate year up to $20 \mathrm{~cm}$ in set row under tillage practices gave the maximum net returns (Rs.31904/ha) with B: C ratio of 1.99. While in Management practices, application of FYM @10 t/ha and kaolin @ 4\% spray $\left(\mathrm{M}_{1}\right)$ gave the maximum net returns (Rs.36791/ha) with B: C ratio of 2.05 as compared to rest of treatments.

\section{Introduction}

Groundnut is the important oilseed crop of the India and rank first among the edible oilseed group. The crop has its own importance due to its high edible oil and high nutritional value of kernel as human food and haulm as rich feed for cattle. Groundnut kernel contains 45$50 \%$ oil, 27 to $33 \%$ protein as well as essential minerals, carbohydrates and vitamins. Success of dry farming depends on soil and crop management practices. The 
medium black soils of this region are poor in structure. They are high in clay content (45 to $60 \%$ ) and are plastic. Organic matter content is low due to high temperature and low rainfall. Also due to high wind speed, rate of evaporation and transpiration is high. Soil cracking is common phenomenon in medium black soil due to which moisture loss is quit high and ultimately affect the crop production drastically. To handle the moisture stress conditions during dry spells mid drought corrections are also necessary to sustain the productivity of crops. Hence investigation was planned to evoke ideal tillage practices along with soil management for increasing the soil reserve in set row cultivation which is followed conventionally in this region and to minimize the loss of water through transpiration.

\section{Materials and Methods}

The field experiment was conducted at Main Dry Farming Research station, Junagadh Agricultural University, Targhadia (Dist.:Rajkot, Gujarat, India) during six consecutive kharif season of 2011-12 to 2016-17. The physical measure of soil viz. field capacity $(33.8 \%)$, Wilting point (17.0\%), Infiltration rate $(10.4 \mathrm{~mm} / \mathrm{hr})$, apparent specific gravity $(1.34 \mathrm{~g} / \mathrm{cc})$, Maximum WHC (47.0\%) and soil texture clayey.

The chemical properties of soil at $0-15 \mathrm{~cm}$ depth had EC $0.28 \mathrm{mmhos} / \mathrm{cm}, \mathrm{pH}$ (7.75), organic carbon (OC) $0.497 \%$, Available $\mathrm{P}_{2} \mathrm{O}_{5}$ $24.4 \mathrm{~kg} / \mathrm{ha}$, Available $\mathrm{K}_{2} \mathrm{O} 448 \mathrm{~kg} / \mathrm{ha}$. The experiment included total 10 treatment combinations viz. Main factor involve 2 levels of tillage $\mathrm{T}_{1}$-Ploughing every year up to $20 \mathrm{~cm}$ in set row, $\mathrm{T}_{2}$ - Ploughing alternate year up to 20 $\mathrm{cm}$ in set row and sub factor involve five different management practices i.e. $\mathrm{M}_{1}$ - FYM

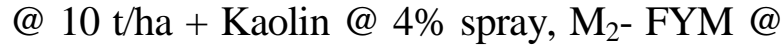
10 t/ha + Guar gum @ $0.3 \%$ spray, $\mathrm{M}_{3-}$ Gypsum@1t/ha + Kaolin@ @\% spray, M4-
Gypsum@1t/ha + Guar gum @ 0.3\% spray, $\mathrm{M}_{5-}$ Control each replicate four times in split plot design with the plot size of (a) gross plot size: $5.0 \mathrm{~m} \mathrm{x} 4.8 \mathrm{~m}$, (b) net plot size: $3.2 \mathrm{~m} \mathrm{x} 2.4$ $\mathrm{m}$. The spacing and seed rate were $60 \mathrm{~cm} \times 10$ $\mathrm{cm}$ and $100 \mathrm{~kg} / \mathrm{ha}$ respectively. The crop was fertilized with 12.5:25.0:0.0 NPK kg /ha.

\section{Results and Discussion}

\section{Pod and haulm yield of groundnut}

\section{Effect of tillage practices}

The pooled results of six years presented in (Table 1) revealed that maximum pod yield $(1110 \mathrm{~kg} / \mathrm{ha})$ was recorded under the ploughing every year up to $20 \mathrm{~cm}$ in set raw $\left(\mathrm{T}_{1}\right)$ over the ploughing alternate year up to $20 \mathrm{~cm}$ in set $\operatorname{raw}\left(\mathrm{T}_{1}\right)$. These results confirm the findings of Bhatnagar et al., (1983) and G. S. Sutaria et al., (2010). The haulm yield of groundnut was not affected significantly due to tillage practices. On the basis of pooled results, it was recorded higher $(3863 \mathrm{~kg} / \mathrm{ha})$ under ploughing alternate year up to $20 \mathrm{~cm}$ in set row $\left(\mathrm{T}_{2}\right)$.

\section{Effect of management practices}

Results in table 1 shows that pod yield of groundnut were affected due to management practices. On the basis of pooled results maximum pod (1257 kg/ha) and haulm (4023 $\mathrm{kg} / \mathrm{ha}$ ) yield of groundnut was obtained under application of FYM@10 t/ha and kaolin@4\% spray $\left(\mathrm{M}_{1}\right)$ as compared to rest of management practices. The findings are close with findings of Balasubramanian et.al.(1997) and Naveen et. al. (1992).

\section{Interaction effect}

Interaction effect of tillage and management practices ( $\mathrm{T} \mathrm{X} \mathrm{M)} \mathrm{was} \mathrm{found} \mathrm{non-significant}$ during all the six years and pooled results in respect of pod and haulm yield of groundnut. 
Table.1 Effect of different treatments on yield, water use efficiency and economics of groundnut crop (Pooled result of six years)

\begin{tabular}{|c|c|c|c|c|c|c|c|}
\hline $\begin{array}{l}\text { Sr } \\
\dot{\mathbf{N}} \\
\mathbf{0 .}\end{array}$ & Treatments & $\begin{array}{c}\text { Pod } \\
\text { yield } \\
\text { (kg/ha) }\end{array}$ & $\begin{array}{c}\text { Haulm } \\
\text { yield } \\
\text { (kg/ha) }\end{array}$ & $\begin{array}{c}\text { Rain water } \\
\text { use } \\
\text { efficiency } \\
\text { (kg/ha- } \\
\text { mm) }\end{array}$ & $\begin{array}{c}\text { Crop } \\
\text { water use } \\
\text { efficiency } \\
\text { (kg/ha- } \\
\text { mm) }\end{array}$ & $\begin{array}{c}\text { Net } \\
\text { returns } \\
\text { (Rs./ha) }\end{array}$ & $\begin{array}{l}\text { B:C } \\
\text { ratio }\end{array}$ \\
\hline $\mathbf{A}$ & \multicolumn{7}{|l|}{ Tillage practices (T): Two } \\
\hline 1. & $\begin{array}{l}\text { Ploughing every year up } \\
\text { to } 20 \mathrm{~cm} \text { in set row }\left(T_{1}\right)\end{array}$ & 1110 & 3683 & 2.04 & 3.27 & 31218 & 1.95 \\
\hline 2. & $\begin{array}{l}\text { Ploughing alternate year } \\
\text { up to } 20 \mathrm{~cm} \text { in set row } \\
\left(\mathrm{T}_{2}\right)\end{array}$ & 1083 & 3863 & 2.01 & 3.18 & 31904 & 1.99 \\
\hline & S. Em. \pm & 21 & 86 & - & - & - & - \\
\hline & C.D.at $5 \overline{\%}$ & NS & NS & - & - & - & - \\
\hline & C.V.\% & 16.95 & 13.42 & - & - & - & - \\
\hline B. & \multicolumn{7}{|c|}{ Management practices (M): Five } \\
\hline 1. & $\begin{array}{l}\text { FYM @ } 10 \text { t/ha + } \\
\text { Kaolin @ 4\% spray } \\
\left(\mathrm{M}_{1}\right)\end{array}$ & 1257 & 4023 & 2.31 & 3.68 & 36791 & 2.05 \\
\hline 2. & $\begin{array}{l}\text { FYM @ } 10 \text { t/ha + Guar } \\
\text { gum @ } 0.3 \% \text { spray }\left(\mathrm{M}_{2}\right)\end{array}$ & 1134 & 3840 & 2.11 & 3.43 & 31703 & 1.92 \\
\hline 3. & $\begin{array}{l}\text { Gypsum @ } 1 \mathrm{t} / \mathrm{ha}+ \\
\text { Kaolin@ @\% spray } \\
\left(\mathrm{M}_{3}\right)\end{array}$ & 1110 & 3855 & 2.05 & 3.26 & 31888 & 1.96 \\
\hline 4. & $\begin{array}{l}\text { Gypsum@ } 1 \text { t/ha + Guar } \\
\text { gum@ } 0.3 \% \text { spray }\left(\mathrm{M}_{4}\right)\end{array}$ & 1058 & 3698 & 1.96 & 3.11 & 29858 & 1.93 \\
\hline \multirow[t]{3}{*}{5.} & Control $\left(\mathrm{M}_{5}\right)$ & 923 & 3449 & 1.67 & 2.73 & 27544 & 1.99 \\
\hline & S.Em. \pm & 23 & 48 & - & - & - & - \\
\hline & C.D.at $5 \%$ & 64 & 133 & - & - & - & - \\
\hline C. & \multicolumn{5}{|c|}{ Interaction Effect of TxM : } & & \\
\hline & S.Em.t & 32 & 67 & - & - & - & - \\
\hline & C.D.at $5 \%$ & NS & NS & - & - & - & - \\
\hline & C.V.\% & 11.76 & 8.75 & - & - & - & - \\
\hline
\end{tabular}

Rain water use efficiency and crop water use efficiency

Rain water use efficiency and crop water use efficiency (Table 1) was also calculated under different treatments of tillage and management practices during all the years. In case of tillage practices maximum rain water use efficiency $(2.04 \mathrm{~kg} / \mathrm{ha}-\mathrm{mm})$ and crop water use efficiency $(3.27 \mathrm{~kg} / \mathrm{ha}-\mathrm{mm})$ was obtained in ploughing carried out every year up to $20 \mathrm{~cm}$ in set row $\left(\mathrm{T}_{1}\right)$, while in management practices the application of FYM @ 10 t/ha + Kaolin @ 4\% spray $\left(\mathrm{M}_{1}\right)$ recorded maximum rain water use efficiency (2.31 kg/ha-mm) and crop water use efficiency (3.68 kg/ha-mm). These results confirm the findings of Raskar and Bhoi (2003) and Kumar and Rana (2007)

\section{Economics}

The data in table 1 indicated that ploughing carried out in alternate year up to $20 \mathrm{~cm}$ in set 
row under tillage practices gave the maximum net returns (Rs.31904/ha) with B: C ratio of 1.99. While in Management practices, application of FYM @ 10 t/ha and kaolin@ $4 \%$ spray $\left(\mathrm{M}_{1}\right)$ gave the maximum net returns (Rs.36791/ha) with B: C ratio of 2.05 as compared to rest of treatments. Similar results were reported by Trivedi et.al. (1994)

It is concluded that application FYM @ 10 t/ha and kaolin @ 4\% spray (400gm/10 liter water) at dry spell gave higher productivity and net returns as well as maximum rain and crop water use efficiency under dry farming conditions.

\section{References}

Balasubramanian, P and Palaniappan, S. P., 1997, Influence of organic and inorganic manuaring and split application of $\mathrm{NK}$ on root nodulation and pod yield in groundnut. Madras Agric. J., 83(3):198-200.

Bhatnagar, V. K., Chaudhary, T. N. and Sharma, B. R. (1983). Effect of tillage and residue management on properties of two coarse textured soils and yield of irrigates wheat and groundnut. Soil and Tillage Res., 3(1):27-37.

Kadu, S. P., D. B. Patel, R. B. Patel and A. P. Patel. (2004): Effect of Moisture Stress and Evapo-trasnpiration Suppressants on Growth and Yield of Summer
Groundnut (Arachis hypogaea L.). Trends in Biosciences 7(22): 36283632.

Kumar, A. and Rana, K.S. 2007. Performance of pigeonpea + green gram intercropped system as influenced by moisture conservation practice and fertility levels under rainfed conditions. Indian Journal of Agronomy 52(1): 31-35.

Naveen, P., Daniel, K. V., Subramanian, P., Kumar, P. S. (1992): Response of irrigated groundnut (Arachis hypogaea L.) to moisture stress and its management. Indian J. Agron., 37, 8285.

Raskar, B. S and Bhoi, P. G., (2003). Response of summer Groundnut (Arachis Hypogea L.) to irrigation regime and mulching. Indian Journal of Agronomy. 48(3):210-213.

Sutaria, G. S., M. V. Ramdevputra, K. N. Akbari, V. D. Vora and D. R. Padmani(2010), Effect of tillage and nutrient management on yield of groundnut and soil fertility. Legume Res. 33(2): 131-133.

Trivedi, D. V., Ahalawat, R. P. S. and Trivedi, S. J.(1994). Effect of varying irrigation schedule, depth of ploughing and mulches on growth and yield of summer green gram. Indian journal of Agronomy 39(4): 667-669.

\section{How to cite this article:}

Vekaria. P.D., V.D. Vora, T.J. Patel, J.T. Patel, G.R. Sharma, H.R. Vadar and Hirpara. D.S. 2020. Rainwater Management for Sustaining Groundnut Productivity under Dry Farming Conditions. Int.J.Curr.Microbiol.App.Sci. 9(01): 2033-2036.

doi: https://doi.org/10.20546/ijcmas.2020.901.230 